\title{
Preplant Fungicide Dips of Strawberry Transplants to Control Anthracnose Caused by Colletotrichum acutatum in California
}

\author{
Oleg Daugovish ${ }^{1,3}$, Hai Su², and W. Douglas Gubler ${ }^{2}$
}

ADDITIONAL INDEX WORDS. crown rot, Fragaria $\times$ ananassa, root rot, strobilurin

SUMMARY. Bare-root daughter plants of strawberry (Fragaria $\times$ ananassa) were inoculated with Colletotrichum acutatum, the cause of crown rot, root rot, and fruit rot of strawberry in California. Plants were subsequently dipped in fungicide solutions or washed with running tap water immediately before planting in Summer and Fall 2002 and Fall 2004. Fungicide treatments reduced plant dieback by up to $\mathbf{9 2 \%}$ in fruit production fields. Plants treated with azoxystrobin, the premixtures of boscalid + pyraclostrobin and cyprodinil + fludioxonil had $50 \%$ to $92 \%$ reduction in disease incidence, increased canopy size by more than $100 \%$, and produced significantly higher marketable yields in all planting dates than the inoculated plants that were not treated with the fungicides. Chlorothalonil and captan also significantly reduced disease incidence but did not consistently increase marketable yield compared with the untreated, inoculated control. The effects of propiconazole and trifloxystrobin were inconsistent in reducing disease incidence. Water wash did not reduce root and crown disease incidence but significantly increased marketable yields by $13 \%$ over the untreated, inoculated controls in one of two plantings. No pretransplant treatments provided protection against fruit and foliar infection; thus, in-season fungicide applications would be necessary for disease control in commercial production fields if environmental conditions favored disease development.

$\mathrm{T}$ The United States is the largest producer of strawberries in the world, with over $85 \%$ of fresh market fruit produced in California (U.S. Department of Agriculture, 2005). Anthracnose, caused by Colletotrichum acutatum, is a major disease in strawberry production in the United States (Gunnell and Gubler, 1992) and continues to be a problem elsewhere worldwide (Bobev et al., 2002; Dai et al., 2006; Denoyes and Baudry, 1995; Freeman and Katan, 1997; Henz et al., 1991; Stensvand et al., 2001). The pathogen can infect all parts of the strawberry plant, resulting in substantial losses in fruit production (Freeman and Katan,

The University of California Hansen Trust is acknowledged for partial funding of this project.

We thank Dr. Jerry Uyemoto (U.S. Department of Agriculture) and Dr. Jim Downer (University of California Cooperative Extension, Ventura County, CA) for critical review of the manuscript. We also thank Conroy Farms and Reiter Affiliated Companies for their collaboration.

${ }^{1}$ University of California Cooperative Extension, Ventura County, Ventura, CA 93003

${ }^{2}$ Department of Plant Pathology, University of California, Davis, CA 95616

${ }^{3}$ Corresponding author. E-mail: odaugovish@ucdavis. edu.
1997; Henz et al., 1991). Severe anthracnose infections from nurserygrown planting stocks caused loss of marketable yield up to $40 \%$ during the 2001-02 season in some fall-planted strawberry fields in Ventura County, CA; losses were estimated at $\$ 3000$ per acre (Daugovish et al., 2004). Thus, management strategies that include preventive measures are needed to control anthracnose on plants before transplanting to production fields.

There are many potential sources of inoculum. Eastburn and Gubler
(1990) showed the presence of inoculum in soil particles that were adhering to the roots and crowns of strawberry plants from the nursery. In addition, nursery surveys and greenhouse studies clearly indicated that anthracnose inoculum may come from diseased strawberry volunteers, rotation crops, and weed hosts in neighboring fields (Gubler et al., 2006). Infected nursery plants are generally asymptomatic except for a few petiole or stolon lesions. However, after digging and trimming the plants, the disease is difficult to see and the pathogen can be carried long distance on transplants from nurseries to the production fields where it then causes plant stunting or collapse of young plants (Eastburn and Gubler, 1990).

Because the inoculum is usually water-splashed and wind-blown to adjacent fields by sprinkler irrigation or rain, new plants would be ideally grown away from recently harvested fields. However, because of limited land availability, a single site rotation is common in California. Because C. acutatum could survive in buried plant tissues for up to 9 months (Eastburn and Gubler, 1990), and soil moisture and temperature could also affect pathogen survival (Feil et al., 2003), new plantings may be subject to potential infection for several months.

Currently, regular foliar application of fungicides is a common practice to reduce this disease in strawberry nurseries (Koike et al., 2005), but this does not affect crown rot resulting from inoculum in infested soil (Eastburn and Gubler, 1990; Gubler et al., 2006). Control options in fruit production fields are also very limited. Foliar sprays of strobilurin fungicides

\begin{tabular}{llll}
\hline $\begin{array}{l}\text { Units } \\
\begin{array}{l}\text { To convert U.S. to SI, } \\
\text { multiply by }\end{array}\end{array}$ & U.S. unit & Sl unit & $\begin{array}{l}\text { To convert SI to U.S., } \\
\text { multiply by }\end{array}$ \\
\hline 0.4047 & $\mathrm{acre}(\mathrm{s})$ & $\mathrm{ha}$ & 2.4711 \\
29.5735 & $\mathrm{fl} \mathrm{oz}$ & $\mathrm{mL}$ & 0.0338 \\
0.0781 & $\mathrm{fl} \mathrm{oz} / 100 \mathrm{gal}$ & $\mathrm{mL} \cdot \mathrm{L}^{-1}$ & 12.8000 \\
0.3048 & $\mathrm{ft}$ & $\mathrm{m}$ & 3.2808 \\
3.7854 & gal & $\mathrm{L}$ & 0.2642 \\
25.4 & inch $(\mathrm{es})$ & $\mathrm{mm}$ & 0.0394 \\
6.4516 & inch & $\mathrm{cm}$ & 0.1550 \\
0.4536 & $\mathrm{lb}$ & $\mathrm{kg}$ & 2.2046 \\
1.1983 & $\mathrm{lb} / 100 \mathrm{gal}$ & $\mathrm{g} \cdot \mathrm{L}^{-1}$ & 0.8345 \\
1.1209 & $\mathrm{lb} / \mathrm{acre}$ & $\mathrm{kg} \cdot \mathrm{ha}^{-1}$ & 0.8922 \\
0.0749 & $\mathrm{oz} / 100 \mathrm{gal}$ & $\mathrm{g} \cdot \mathrm{L}^{-1}$ & 13.3526 \\
1.2500 & $\mathrm{pt} / 100 \mathrm{gal}$ & $\mathrm{mL} \cdot \mathrm{L}^{-1}$ & 0.8000 \\
$\left({ }^{\circ} \mathrm{F}-32\right) \div 1.8$ & ${ }^{\circ} \mathrm{F}$ & ${ }^{\circ} \mathrm{C}$ & $\left(1.8 \times{ }^{\circ} \mathrm{C}\right)+32$ \\
& & &
\end{tabular}

Horflechnology • April-June 2009 19(2) 
and captan have suppressed disease incidence of fruit rot (Black et al., 1990; Freeman et al., 1997; Su and Gubler, 2006). However, infections of the root system were not controlled by aboveground fungicide applications.

Additional control measures for transplants could reduce the infection on transplants or infestation of soil attached to transplants to minimize the risk of disease epidemics. Eastburn and Gubler (1990) reported that infested plants and soil adhering to transplants directly contributed to disease epidemics in fruit production fields, and that washing of transplants with running tap water removed soil and fungal spores and resulted in excellent disease control. Fungicide dipping may also suppress the pathogen. The objectives of this study were to evaluate the effects of preplant fungicide dips and water washing of nursery plants for anthracnose control in fruit production fields.

\section{Materials and methods}

Plant inoculation and treatMENT. Three isolates of C. acutatum isolated from diseased strawberry plants from Salinas, CA, were grown on potato dextrose agar amended with $0.01 \%$ tetracycline (PDA-tet) for $20 \mathrm{~d}$. Conidia were harvested from these cultures with a bent glass rod in $10 \mathrm{~mL}$ of sterile water. The conidial suspension was filtered through two layers of cheese cloth to remove mycelial fragments and was adjusted to $1.5 \times 10^{7}$ spores $/ \mathrm{mL}$ using a hemacytometer (Hausser Scientific, Horsham, PA).

Bare-root strawberry transplants were removed from a $-2{ }^{\circ} \mathrm{C}$ storage facility and brought to about $25^{\circ} \mathrm{C}$ for $\approx 4$ h. A day-neutral cultivar (Baeza) was used for summer planting on 22 July 2002 for summer fruit production, and a short day cultivar (Camarosa) for fall planting on 15 Oct. 2002 and 9 Oct. 2004 for winter fruit productions. The conidial suspension was applied with a hand-held sprayer at $300 \mathrm{~mL}$ of suspension per 100 plants. Fifty plants were sprayed with tap water to serve as a noninoculated control and were placed in isolated plastic bags and separated from the inoculated plants. Another 50 inoculated plants served as inoculated controls. Neither noninoculated nor inoculated controls were treated with fungicides.
Immediately after inoculation, the plants were placed into crates to dry for $20 \mathrm{~min}$ and were then placed into a cooler for transport to field sites at Oxnard, CA. Within 48 h of inoculation, lots of 50 inoculated transplants were agitated for $30 \mathrm{~s}$ in fungicide solutions prepared in $20-\mathrm{L}$ buckets (Table 1). For water wash treatment, transplants inoculated with C. acutatum but not treated with fungicides were washed with running tap water for $30 \mathrm{~s}$ to remove soil particles adhered to the crown and roots.

Planting and data collecTION. The plot sites were established in commercial fields that were flat fumigated with methyl bromide/ chloropicrin $(67 \% / 33 \%)$ at a rate of $300 \mathrm{lb} / \mathrm{acre}$. The plastic tarp was removed 25 to $30 \mathrm{~d}$ after fumigation. The beds were shaped $6 \mathrm{ft}$ wide, $2 \mathrm{ft}$ high, and $300 \mathrm{ft}$ long and were covered with black polyethylene mulch. Planting holes were cut after mulch installation for four planting rows per bed with $1-\mathrm{ft}$ spacing between plants in a row. Transplants were planted through these holes in the plastic mulch immediately after fungicide treatment. Treatments were arranged in a randomized complete block design with four replications of 12 transplants per replicate. Immediately after transplanting, the plants were sprinkler-irrigated for about $\mathrm{l} h$ every other day for 5 weeks. The experiments were managed according to commercial standards except that no foliar fungicides were applied throughout the growing season.

Two-dimensional measurements of plant canopy and the number of plants with visible anthracnose symptoms, including stunting and plant collapse, were recorded on 12 Aug. 2002 (summer production), 9 Nov. 2002 (winter production), and 3 Nov. 2004 (winter production). In all seasons, fruits were harvested weekly and were graded as marketable, anthracnose-diseased, or unmarketable, the latter due to reasons other than anthracnose.

Data analysis. Disease incidence, canopy size, and marketable yield and percentage yield loss from anthracnose-diseased fruit were analyzed using the analysis of variance (ANOVA) procedure in SAS (version 9.2; SAS Institute, Cary, NC). Means separation was conducted using
Fisher's protected least significant difference test at $P=0.05$.

\section{Results}

EFFECT OF FUNGICIDE DIPS AND WATER WASH ON DISEASE INCIDENCE. For all three planting dates, there was a significant treatment effect in reducing plant collapse or crown rot incidence $(P<0.0001)$ (Fig. 1). The inoculated controls developed the highest or second highest disease incidence compared with the all other treatments, while the noninoculated controls had the least incidence of plant collapse. Disease incidence in the waterwashed plants was similar to the inoculated control for both planting dates (Fig. l, B and C).

Disease incidence in plants treated with the premixture of cyprodinil + fludioxonil (Switch ${ }^{\circledR}$; Syngenta Crop Protection, Greensboro, NC), the premixture of boscalid + pyraclostrobin (Pristine ${ }^{\circledR}$; BASF, Florham Park, NJ), and azoxystrobin (Quadris ${ }^{\circledR}$, Syngenta Crop Protection) was not significantly different from the noninoculated control.

Disease incidence in plants treated with cyprodinil + fludioxonil was reduced by $61 \%$ in Summer 2002 production and $83 \%$ in Winter 2004 production over the inoculated control plants. The boscalid + pyraclostrobin treatment reduced disease incidence by $54 \%$ in Summer 2002 and $75 \%$ in Winter 2004, and azoxystrobin by $50 \%$ in Summer 2002 and 92\% in Winter 2004.

Chlorothalonil (Bravo Weather Stik ${ }^{\circledR}$, Syngenta Crop Protection) significantly reduced plant collapse to a level similar to the noninoculated control in Winter 2004 production (Fig. 1C). Disease incidence compared with the inoculated control was reduced by $42 \%$ to $58 \%$ in all three plantings.

Plants treated with captan (Cap$\tan ^{\mathrm{TM}}$; Arysta LifeScience North America, Cary, NC) had disease incidence similar to the noninoculated control in two of three plantings (Fig. 1, B and $\mathrm{C}$ ) and also had significantly lower disease incidence than the inoculated control in all three plantings. The combination of captan with the premixtures of boscalid + pyraclostrobin or of cyprodinil + fludioxonil did not significantly reduce disease incidence compared with the single product treatment (Fig. 1C). 
Table 1. Fungicide dip treatments of strawberry transplants after inoculated with Colletotrichum acutatum at Oxnard, CA, on 22 July and 15 Oct. 2002, and on 9 Oct. 2004.

\begin{tabular}{|c|c|c|}
\hline Treatment $^{\mathrm{z}}$ & Formulated product ${ }^{\mathrm{y}}$ & $\begin{array}{c}\text { Rate } \\
{\text { (units } / 100 \text { gal })^{\mathrm{x}}}\end{array}$ \\
\hline Azoxystrobin & Quadris ${ }^{\circledR} 2.08 \mathrm{SC}$ & $4 \mathrm{fl} \mathrm{oz}$ \\
\hline $\begin{array}{l}\text { Azoxystrobin + harpin } \\
\text { protein }\end{array}$ & $\begin{array}{l}\text { Quadris }^{\circledR} 2.08 \mathrm{SC}+\text { Messenger }^{\circledR} \\
\text { 3.0WG }\end{array}$ & $4 \mathrm{fl} \mathrm{oz}+54 \mathrm{oz}$ \\
\hline (Boscalid + pyraclostrobin) & Pristine $^{\circledR} 38.5 \mathrm{WG}$ & $6 \mathrm{oz}$ \\
\hline $\begin{array}{l}\text { (Boscalid }+ \\
\text { pyraclostrobin })+ \text { captan }\end{array}$ & $\begin{array}{l}\text { Pristine }^{\circledR} 38.5 \mathrm{WG}+\text { Captan }^{\mathrm{TM}} \\
\text { 50WP }\end{array}$ & $6 \mathrm{oz}+5 \mathrm{lb}$ \\
\hline Captan & Captan $^{\mathrm{TM}} 50 \mathrm{WP}$ & $5 \mathrm{lb}$ \\
\hline Chlorothalonil & $\begin{array}{l}\text { Bravo Weather } \\
\text { Stik }{ }^{\circledR} \text { 6SC }\end{array}$ & 2 pint \\
\hline (Cyprodinil + fludioxonil) & Switch $^{\circledR} 62.5 \mathrm{WG}$ & $5 \mathrm{oz}$ \\
\hline $\begin{array}{l}\text { (Cyprodinil + fludioxonil })+ \\
\text { captan }\end{array}$ & $\begin{array}{l}\text { Switch }^{\circledR} 62.5 \mathrm{WG}+\text { Captan }^{\mathrm{TM}} \\
\text { 50WP }\end{array}$ & $5 \mathrm{oz}+5 \mathrm{lb}$ \\
\hline Kresoxim-methyl & Sovran $^{\circledR} 50 \mathrm{WG}$ & $6.4 \mathrm{oz}$ \\
\hline Propiconazole & Tilt $^{\circledR} 250 \mathrm{EC}$ & $2 \mathrm{fl} \mathrm{oz}$ \\
\hline Pyrimethanil & Scala $^{\circledR} 600 \mathrm{SC}$ & $18 \mathrm{fl} \mathrm{oz}$ \\
\hline Trifloxystrobin & Flint $^{\circledR} 50 \mathrm{WG}$ & $2 \mathrm{oz}$ \\
\hline $\begin{array}{l}\text { Untreated inoculated } \\
\text { control }\end{array}$ & $-{ }^{\mathrm{w}}$ & \\
\hline $\begin{array}{l}\text { Untreated noninoculated } \\
\text { control }\end{array}$ & - & \\
\hline Water wash & - & \\
\hline
\end{tabular}

${ }^{2}$ Treatments were adjusted based on their effectiveness in disease control, growth promotion, and marketable yield. Water wash was not applied on 22 July 2002. Treatment azoxystrobin + harpin protein was only applied on 15 Oct. 2002. Kresoxim-methyl, propiconazole, and trifloxystrobin were not further tested on 9 Oct. 2004; instead treatments (boscalid + pyraclostrobin) + captan, (cyprodinil + fludioxonil) + captan, and pyrimethanil were added in the test. Fungicides with “+” in parenthesis were premixed, otherwise they were tank-mixed during treatment. ${ }^{y}$ Bravo Weather Stik ${ }^{\circledR}$, Quadris ${ }^{\circledR}$, Switch $^{\circledR}$, Tilt ${ }^{\circledR}$ (Syngenta Crop Protection, Greensboro, NC); Pristine ${ }^{\circledR}$, Sovran $^{\circledR}$ (BASF, Florham Park, NJ); Captan ${ }^{\text {TM }}$ (Arysta LifeScience North America, Cary, NC); Flint ${ }^{\circledR}$, Scala ${ }^{\circledR} 600$ SC $($ Bayer CropScience, Research Triangle Park, NC); Messenger ${ }^{\circledR}$ (Eden Bioscience, Bothell, WA).

${ }^{x} 1 \mathrm{fl} \mathrm{oz} / 100 \mathrm{gal}=0.0781 \mathrm{~mL} \cdot \mathrm{L}^{-1}, 1 \mathrm{oz} / 100 \mathrm{gal}=0.0749 \mathrm{~g} \cdot \mathrm{L}^{-1}, 1 \mathrm{lb} / 100 \mathrm{gal}=1.1983 \mathrm{~g} \cdot \mathrm{L}^{-1}, 1 \mathrm{pint} / 100 \mathrm{gal}=$ $1.2500 \mathrm{~mL} \cdot \mathrm{L}^{-1}$

"Not applicable.

Trifloxystrobin (Flint $\AA$; Bayer CropScience, Research Triangle Park, $\mathrm{NC})$ and propiconazole (Tilt ${ }^{\circledR}$; Syngenta Crop Protection) did not give consistent results in the two plantings tested. Trifloxystrobin-treated plants did not reduce disease incidence significantly compared with the inoculated control in Summer 2002 production, but did so in Winter 2002 production, where disease levels were similar to the noninoculated control. Transplants treated with kresoxim-methyl (Sovran ${ }^{\circledR}$; BASF) had higher or similar disease incidence to the inoculated control (Fig. 1, A and B).

EFFECT OF TREATMENTS ON PLANT GROWTH. In Summer 2002, inoculation with $C$. acutatum resulted in severe infection and reduction of plant size $(P=0.01)$ (Fig. $2 \mathrm{~A})$. The inoculated plants were $63 \%$ smaller than the noninoculated plants. The inoculated plants dipped in azoxystrobin and cyprodinil + fludioxonil were $69 \%$ and $101 \%$ larger, respectively, than the inoculated control plants. Canopy sizes were also significantly larger in the plots treated with boscalid + pyraclostrobin, captan, and chlorothalonil $(63 \%, 52 \%$, and $34 \%$, respectively) compared with those of the inoculated plants. However, canopy size in plots treated with trifloxystrobin or propiconazole were not significantly different $(P>0.05)$ from the inoculated plants. Plants treated with kresoxim-methyl had $43 \%$ smaller canopy than the inoculated control.

In Winter 2002, there was also a treatment effect on canopy size $(P=$ 0.012 ) (Fig. 2B). The inoculated plants were $48 \%$ smaller than the noninoculated plants (Fig. 2B). Plants treated with cyprodinil + fludioxonil, azoxystrobin, and boscalid + pyraclostrobin were two times larger than those inoculated plants $(P<0.001)$. Plants treated with trifloxystrobin, and azoxystrobin tankmixed with harpin, had significantly larger plant size than the inoculated control but smaller size than the noninoculated control. Plant sizes were similar among the treatments of chlorothalonil, captan, kresoxim-methyl, propiconazole, water wash, and the inoculated control.

In Winter 2004, plant sizes in all treatments were similar $(P=0.09)$, except the plants dipped in cyprodinil + fludioxonil, where plants were $61 \%$ larger than the inoculated plants (Fig. 2C). The canopy size of the plants treated with captan in combination with cyprodinil + fludioxonil or boscalid + pyraclostrobin was similar to the stand-alone treatments with these fungicides.

EFFECT OF TREATMENTS ON MARKETABLE YIELD. There were significant treatment effects on marketable yield in Summer 2002, Winter 2002 , and Winter $2004(P<0.001, P=$ 0.005 , and $P<0.001$, respectively). In Summer 2002, fruit harvest was discontinued after 3 weeks due to severe disease in all treatments except the noninoculated control and the cyprodinil + fludioxonil treatments (Fig. $3 \mathrm{~A})$. Overall, the inoculated plants had $89 \%$ lower marketable yield than the noninoculated control plants. Marketable yield from plants that were dipped in cyprodinil + fludioxonil was $33 \%$ lower compared with yields from the noninoculated control plants. Treatments of boscalid + pyraclostrobin, azoxystrobin, chlorothalonil, captan, trifloxystrobin, propiconazole, and kresoxim-methyl had $65 \%$ to $94 \%$ less marketable yield than the noninoculated plants due to fruit infection. Plants treated with cyprodinil + fludioxonil, boscalid + pyraclostrobin, azoxystrobin, and chlorothalonil had significantly higher yields than the inoculated control plants. Marketable yield of plants treated with captan, trifloxystrobin, propiconazole, and kresoxim-methyl was not significantly different from that of the inoculated control plants $(P=$ $0.16)$.

In Winter 2002, the inoculated plants produced $48 \%$ less marketable yield than the noninoculated control plants (Fig. 3B). Marketable yields from treatment of cyprodinil + fludioxonil, azoxystrobin, and boscalid + pyraclostrobin were significantly higher than the inoculated control, but not significantly different from that of the noninoculated control. 


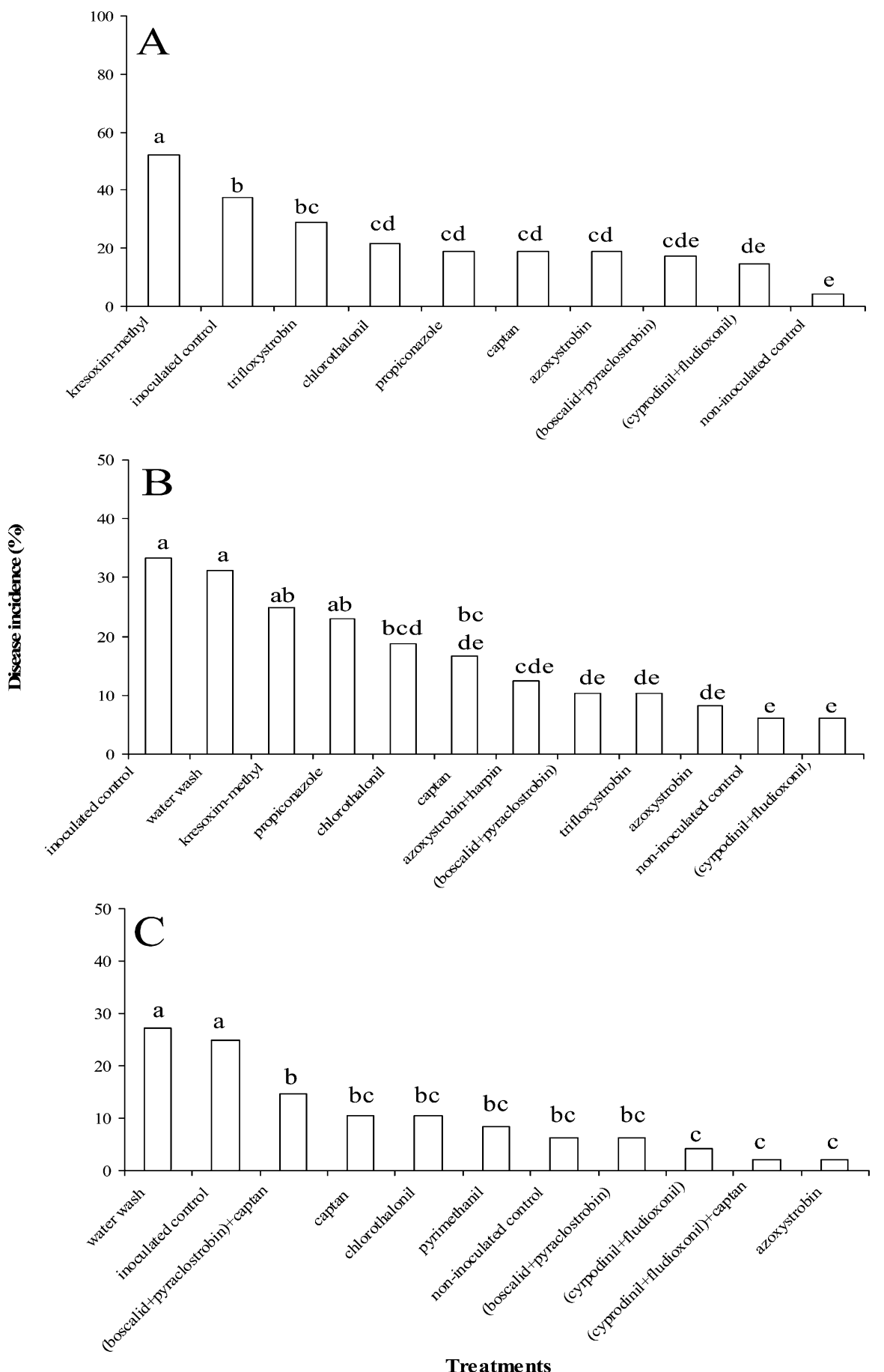

Fig. 1. Disease incidence of strawberry plants at 2 to 3 weeks after planting for 'Baeza' in Summer 2002 (A), and 'Camarosa' in Winter 2002 (B) and 2004 (C) inoculated with Colletotrichum acutatum and dipped in fungicides or washed with water at Oxnard, CA. Treatments with the same letter are not significantly different from each other according to Fisher's protected least significant difference test at $P=0.05$

Treatments with kresoxim-methyl, propiconazole, and trifloxystrobin resulted in $28 \%, 29 \%$, and $36 \%$ higher yields respectively than the inoculated control. Yields in the water wash treatment and the dip treatments with captan, chlorothalonil, or azoxystrobin produced significantly higher marketable yield compared with the inoculated control. Fungicide and water wash treatments resulted in marketable yields similar to the noninoculated control plants, but 13\% higher than the inoculated control. Tank mixtures of captan with cyprodinil + fludioxonil or captan with boscalid + pyraclostrobin did not produce significantly higher marketable yields when compared with single formulated products.

YIELD LOSS DUE TO ANTHRACNOSE ON FRUITS. There were no significant differences in percentage yield loss caused by anthracnose fruit rot among all the treatments in each of the three plantings (data not shown). Yield loss ranged from $3 \%$ to $16 \%$ in Summer 2002 production, in which harvest was discontinued 3 weeks after first harvest because flowers were heavily diseased and no fruits were produced. Yield loss due to anthracnose rot were from $10 \%$ to $23 \%$ in treatments of Winter 2002 production and was less than $1 \%$ for treatments in Winter 2004 production.

\section{Discussion}

Control measures for crown rot caused by $C$. acutatum in strawberry planting stocks were lacking. This study showed that preplant fungicide dips decreased incidence of crown rot collapse at early stages of plant development and significantly increased fruit yields in three seasonal plantings. Plant inoculation showed that fungal spores may be carried via contaminated transplants to new fruit production fields. Infection in roots or crowns caused severe disease and reduced marketable yields.

Azoxystrobin (Quardris $\left.{ }^{\circledR}\right)$, boscalid + pyraclostrobin (Pristine $\left.{ }^{\circledR}\right)$, and cyprodinil + fludioxonil (Switch $\AA$ ) consistently provided effective control of anthracnose early in the season. Before transplants are planted in production fields, dipping in fungicides or being washed with clean water could eradicate spores or other propagules from the planting stocks, thus giving control of the disease. Additional benefits could also be achieved by eliminating other potential pathogens, such as black root rot complexes.

In addition to reduction in disease incidence, we measured increased plant size and fruit yield in azoxystrobin, boscalid + pyraclostrobin, and 

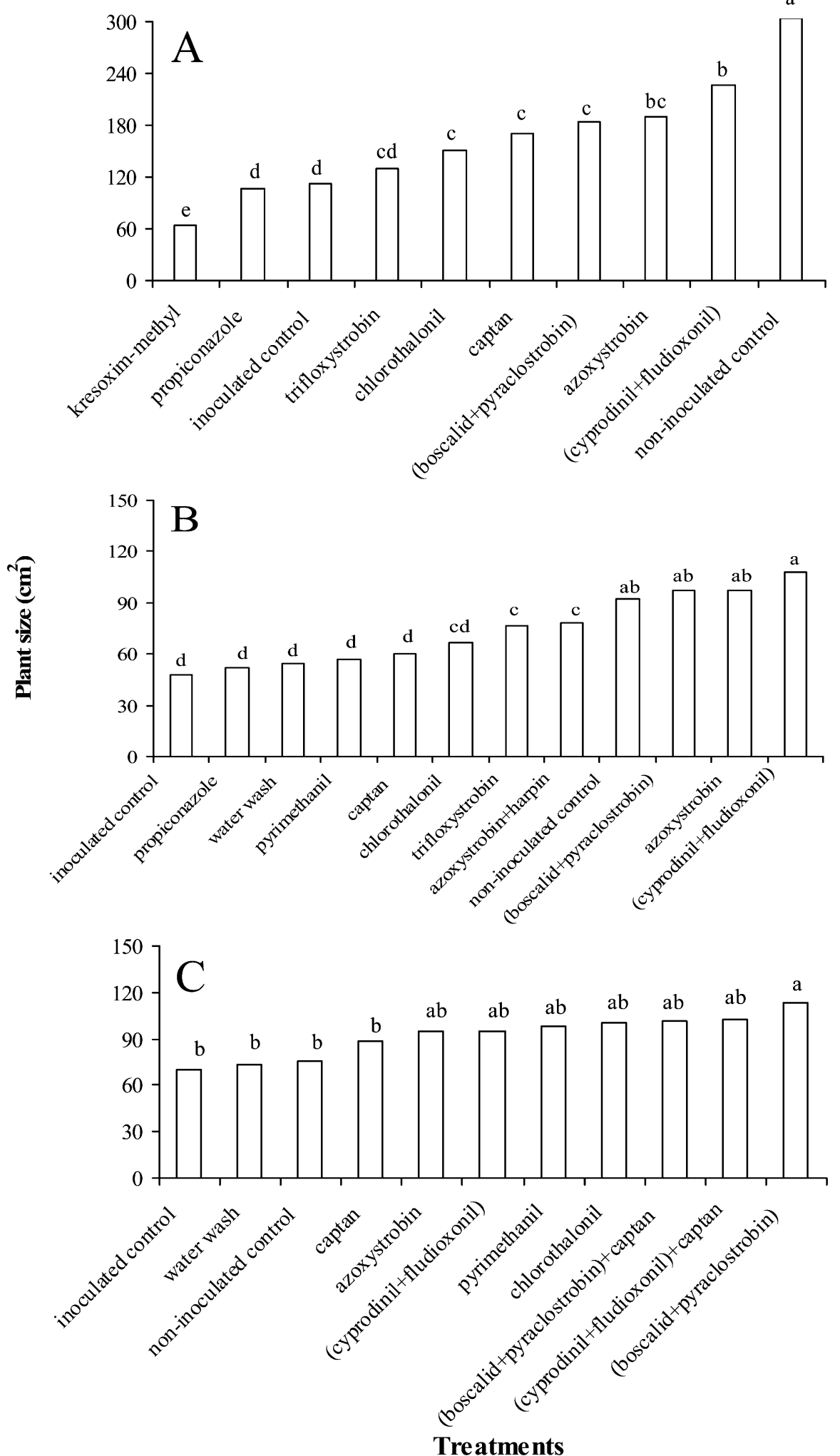

Fig. 2. Canopy size of strawberry plants 2 to 3 weeks after planting for 'Baeza' in Summer 2002 (A), and 'Camarosa' in Winter 2002 (B) and 2004 (C) inoculated with Colletotrichum acutatum and dipped in fungicides or washed with water at Oxnard, CA. Treatments with the same letter are not significantly different from each other according to Fisher's protected least significant difference test at $P=$ $0.05 ; 1 \mathrm{~cm}^{2}=0.1550$ inch $^{2}$. cyprodinil + fludioxonil treatments. The other fungicides also reduced disease incidence, improved plant growth, and increased marketable yield, but the effects were not consistent. Freeman et al. (1997) reported that captan was effective in inhibiting growth of C. acutatum. In our study, captan also decreased disease incidence significantly over the inoculated controls, but was not the most effective fungicide. However, a tank mix of captan with strobilurin fungicides could reduce the potential risk of developing fungicide resistance to strobilurin fungicides in production fields.

In spite of enhancing plant vigor and fruit production, these fungicides applied as preplant treatments did not protect fruit from becoming infected when compared with untreated controls. Also, as expected, fungicide treatment of transplants did not significantly reduce yield loss caused by anthracnose in fruits. Yield increases in fungicide treatments are likely attributable to increased plant size resulting from disease control.

We also observed higher incidence of $C$. acutatum infected fruits in summer plantings compared with winter plantings. This may be attributed to more floral infections due to rainfall (precipitation during harvest period were $1112.2 \mathrm{~mm}$ for Summer 2002, $232.5 \mathrm{~mm}$ for Winter 2002, and $285.4 \mathrm{~mm}$ for Winter 2004 productions). Diseased fruits in noninoculated plots were likely attributable to in-season infection via conidia produced from neighboring infected plants during rainfall events (Ntahimpera et al., 1997). The heavy overhead irrigation also could have caused widespread disease and shortened the harvest period for the experiment in Summer 2002. Foliar fungicides were not used after plots were established. Thus, significantly higher anthracnose-infected fruit and unmarketable yield could be attributed to the spread of the pathogen after planting. With C. acutatum, temperatures near $25^{\circ} \mathrm{C}$ are optimal for conidial germination and plant infection (King et al., 1997; Wilson et al., 1990). Hence, the rapid initiation of flowering, characteristic for day-neutral cultivar Baeza coupled with sprinkler irrigations and averaged day-night air temperatures 21 to $23^{\circ} \mathrm{C}$ in the first 2 weeks in Summer 2002, resulted in a rapid disease spread, and 


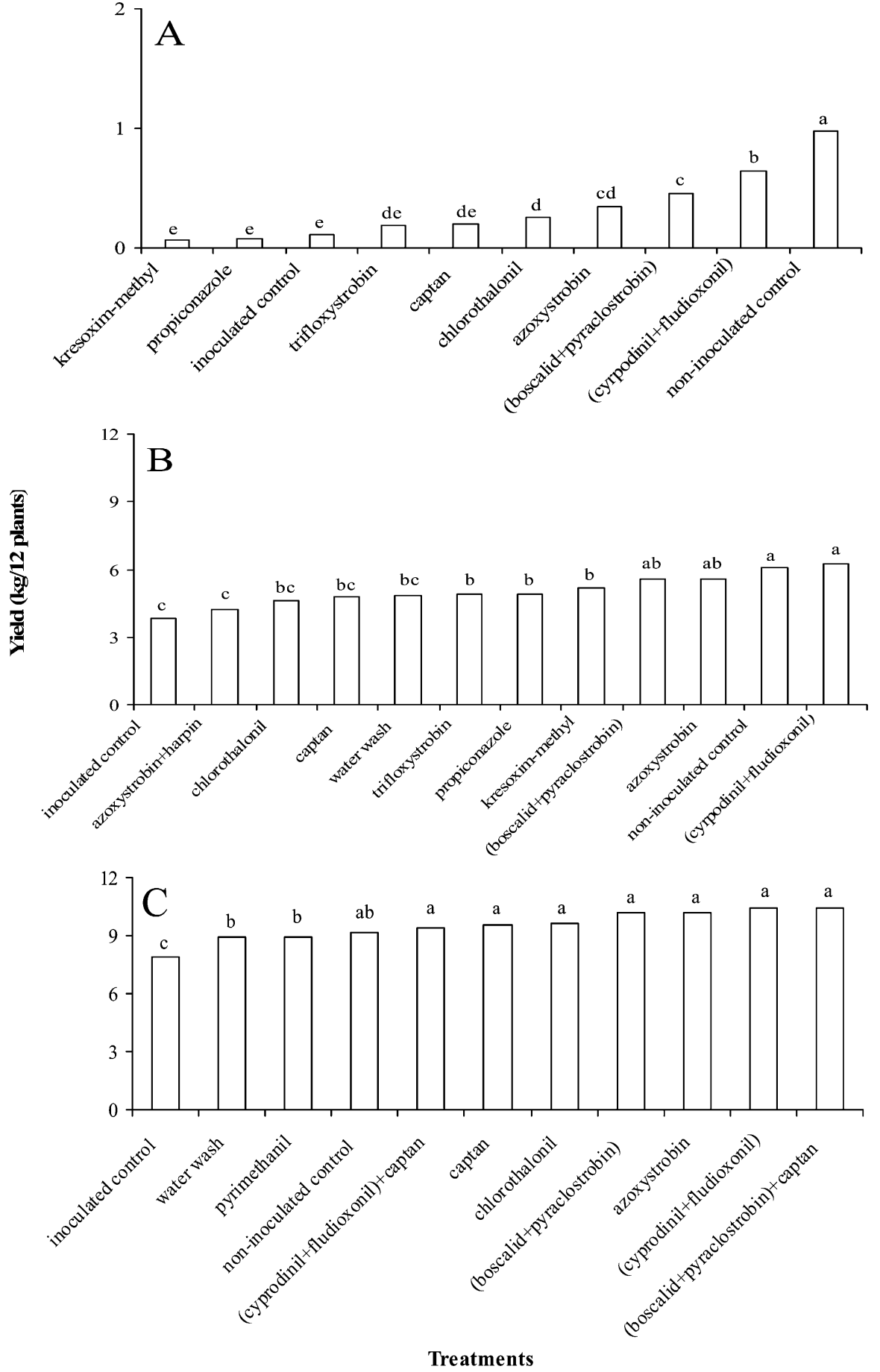

Fig. 3. Marketable fruit yield of strawberry 'Baeza' (9 Sept. to 4 Dec. 2002) (A), 'Camarosa' (24 Jan. to 13 May 2003) (B), and 'Camarosa' (31 Jan. to 30 June 2005 ) (C) inoculated with Colletotrichum acutatum and dipped in fungicides or washed with water at Oxnard, CA. Treatments with the same letter are not significantly different from each other according to Fisher's protected least significant difference test at $P=0.05 ; 1 \mathrm{~kg}=2.2046 \mathrm{lb}$.

stunted plants failed to produce marketable fruit.

During winter production, the effect of $C$. acutatum inoculations and infections on plant size and fruit yields was not pronounced, and of yield loss is likely because rainfall occurred earlier in the harvest period when less fruits were available; plants produced higher marketable yield later in the season.

Preplant fungicide dips would not be expected to protect aboveground plant parts from infection by inoculum dispersed from other sources. Thus, foliar applications are necessary for protection against fruit infection in production fields (Su et al., 2005; Su and Gubler, 2006).

As expected, water wash treatments did not increase plant size; this is because water wash only reduced the inoculum that had not established quiescent infection in plants (Freeman and Sharon, 2001). However, wash treatments increased marketable yield in Winter 2004 production. The increase in marketable yields is likely an effect of reduced inoculum density; disease severity was light due to reduced pathogen growth in winter months. Increase in washing time may enhance the effectiveness. In organic production, forced water wash may also be an alternative to fungicide treatment for transplant establishment and increased fruit production.

The results from this study indicated that azoxystrobin, boscalid + pyraclostrobin, and cyprodinil + fludioxonil reduced incidence of plant dieback and collapse after C. acutatum infection was established and appeared to enhance plant recovery when infected. Inoculum density for naturally occurring infections has not been documented and is currently being investigated. Overall, we expected better control with preplant fungicide treatments. Perhaps the high level of $C$. acutatum inoculum used to infect our test plants was a favor. It is unlikely that plants would become contaminated at similar levels and uniformity as those used in this study. Therefore, preplant fungicide dips of azoxystrobin, boscalid + pyraclostrobin, or cyprodinil + fludioxonil and in-season control measures should provide even more benefits in decreasing disease, maximizing fruit production, and preventing economic loss due to anthracnose in production strawberry.

\section{Literature cited} peratures (average day-night range $13-16{ }^{\circ} \mathrm{C}$ ) in the first 2 weeks after transplanting. The yield loss was less than $1 \%$ in all treatments in Winter 2004 production. The low percentage
Black, L.L., T.B. McInnes, and J.M. Gatti, Jr. 1990. Evaluation of fungicides for control of strawberry fruit rots in Louisiana. Adv. Strawberry Res. 9:33-36. 
Bobev, S.G., A. Zveibil, and S. Freeman. 2002. First report of Colletotrichum acutatum on strawberry in Bulgaria. Plant Dis. $86: 1178$.

Dai, F.M., X.J. Ren, and J.P. Lu. 2006. First report of anthracnose fruit rot of strawberry caused by Colletotrichum acutatum in China. Plant Dis. 90:1046.

Daugovish, O. and E.Takele, K.M. Klonsky, and R.M. DeMoura. 2004. Sample costs to produce strawberries: South coast region, Ventura County. I Nov. 2008. <http:// coststudies.ucdavis.edu/files/strawscvent 2004.pdf>.

Denoyes, B. and A. Baudry. 1995. Species identification and pathogenicity study of French Colletotrichum strains isolated from strawberry using morphological and cultural characteristics. Phytopathology 85:53-57.

Eastburn, D.M. and W.D. Gubler. 1990. Strawberry anthracnose: Detection and survival of Colletotrichum acutatum in soil. Plant Dis. 74:161-163.

Feil, W.S., E.E. Butler, J.M. Duniway, and W.D. Gubler. 2003. The effects of moisture and temperature on the survival of Colletotrichum acutatum on strawberry residue in soil. Can. J. Plant Pathol. 25:362370.

Freeman, S. and A. Sharon. 2001. Pathogenic and non-pathogenic lifestyles in Colletotrichum acutatum from strawberry and other plants. Phytopathology 91:986-992.

Freeman, S. and T. Katan. 1997. Identification of Colletotrichum species responsible for anthracnose and root necrosis of strawberry in Israel. Phytopathology 87:516-521.

Freeman, S., Y. Nizani, S. Dotan, S. Evens, and T. Sando. 1997. Control of Colletotrichum acutatum in strawberry under laboratory, green house, and field conditions. Plant Dis. 81:749-752.

Gubler, W.D., H. Su, and A.F. Feliciano. 2006. Detecting potential sources of $\mathrm{Col}$ letotrichum acutatum for infection of new strawberry plantings in California. Phytopathology 96:S43. (Abstr.).

Gunnell, P.S. and W.D. Gubler. 1992. Taxonomy and morphology of Colletotrichum species pathogenic to strawberry. Mycologia 84:157-165.

Henz, G.P., L.S. Boiteux, and C.A. Lopes. 1991. Outbreak of strawberry anthracnose by Colletotrichum acutatum in central Brasil. Plant Dis. 76:212.

King, W.T., L.V. Madden, M.A. Ellis, and L.L. Wilson. 1997. Effect of temperature on sporulation and latent period of Colletotrichum spp. infecting strawberry fruit. Plant Dis. 81:77-84.

Koike, S.T., W.D. Gubler, and G.T. Browne. 2005. University of California pest management guidelines: Strawberry anthracnose. 1 Nov. 2008. <http://www. ipm.ucdavis.edu/PMG/r734101011. html>.

Ntahimpera, N., L.V. Madden, and L.L. Wilson. 1997. Effect of rain distribution alteration on splash dispersal of Colletotrichum acutatum. Phytopathology 87:649-655.

Stensvand, A., G.M. Strømeng, R. Langnes, L.G. Hjeljord, and A. Tronsmo. 2001. First report of Colletotrichum acutatum in strawberry in Norway. Plant Dis. $85: 558$.

Su, H. and W.D. Gubler. 2006. Fungicidal control of botrytis and anthracnose fruit rot in strawberry in California, 2006. Plant Dis. Mgt Rpt. SMF021.

Su, H., W.D. Gubler, and K. Dell. 2005. Fungicidal control of anthracnose and botrytis fruit rot in strawberry in California, 2005. Fungicide and Nematicide Tests 61:SMF041.

U.S. Department of Agriculture. 2005. Commodity highlight. 1 Nov. 2008. <http://www.ers.usda.gov/briefing/ fruitandtreenuts $/>$.

Wilson, L.L., L.V. Madden, and M.A. Ellis. 1990. Influence of temperature and leaf wetness duration on infection of immature and mature strawberry fruit by Colletotrichum acutatum. Phytopathology 80:111-116. 